\title{
ANALISIS PREDIKSI FINANCIAL DISTRESS DENGAN METODE SPRINGATE (S-SCORE) PADA PT GARUDA INDONESIA TBK
}

\author{
Marisa Fitriani \\ Program Studi Manajemen, Sekolah Tinggi Ilmu Ekonomi Bima \\ Marisaindahfitriani16.stiebima@gmail.com \\ Nurul Huda \\ Program Studi Manajemen, Sekolah Tinggi Ilmu Ekonomi Bima \\ Nurulhuda.stiebima@gmail.com
}

\begin{abstract}
Abstrak: Analisis Prediksi Financial Distress Dengan Metode Springate (S-Score) Pada PT Garuda Indonesia Tbk Penelitian ini bertujuan untuk mengetahui seberapa besarnya prediksi financial distress dan potensi kebangkrutan pada PT Garuda Indonesia Tbk. Jenis penelitian deskriptif kuantitatif. Populasi yang digunakan adalah laporan keuangan PT Garuda Indonesia Tbk yang diakses melalui website www.idx.co.id dalam bentuk laporan neraca (posisi keuangan) dan laba rugi selama delapan tahun terakhir yaitu tahun 2011-2018. Teknik sampling yang digunakan yaitu teknik purposive sampling dengan memperoleh sampel selama tujuh tahun terakhir yaitu tahun 2012-2018. Teknik analisis yang digunakan yaitu metode Sprigate Score (S-score) yang menggunakan empat rasio yaitu rasio modal kerja terhadap total aset $\left(\mathrm{X}_{1}\right)$, rasio laba sebelum bunga dan pajak terhadap total aset $\left(\mathrm{X}_{2}\right)$, rasio laba sebelum pajak terhadap total liabilitas $\left(\mathrm{X}_{3}\right)$, dan rasio penjualan terdapap total aset $\left(\mathrm{X}_{4}\right)$ serta menggunakan uji t-test one sample. Hasil penelitian ini diperoleh nilai $t_{\text {hitung }}$ lebih kecil dari pada $t_{\text {tabel }}(-3.628<1.943)$. sehingga hipotesis Ho yang berbunyi yaitu: Sprigate Score (S-Score) pada PT Garuda Indonesia Tbk kurang dari 0.862 dari yang diharapkan diterima yang artinya bahwa PT Garuda Indonesia, Tbk dikategorikan dalam kondisi financial distress dan berpotensi mengalami kebangkrutan selama tujuh tahun terakhir yaitu dari tahun 2012-2018.
\end{abstract}

Kata Kunci: Financial Distress, Kebangkrutan, Springate Score.

Abstract: Analysis of Financial Distress Prediction Using the Springate (S-Score) Method at PT Garuda Indonesia Tbk This study aims to determine the magnitude of financial distress predictions and potential bankruptcy at PT Garuda Indonesia Tbk. This research is a quantitative descriptive study. The population used is the financial statements of PT Garuda Indonesia Tbk which are accessed through the website www.idx.co.id in the form of balance sheet (financial position) and income statement for the last eight years, namely 2011-2018. The sampling technique used is purposive sampling technique by obtaining samples over the past seven years, namely 2012-2018. The analysis technique used is the Sprigate Score ( $S$-score) method that uses four ratios namely the ratio of working capital to total assets (X1), the ratio of profit before interest and tax to total assets (X2), the ratio of profit before tax to total liabilities (X3), and sales ratio to total assets (X4) and using one sample t-test. The results of this study obtained tcount smaller than ttable $(-3,628<1,943)$. so that the Ho hypothesis which reads namely: The Sprigate Score (S-Score) at PT Garuda Indonesia Tbk is less than 0.862 than expected, which means the company is categorized in financial distress and has the potential to go bankrupt during the last seven years, namely from 2012-2018.

Keywords: Financial Distress, Bankruptcy, Springate Score.

\section{PENDAHULUAN}

Era globalisasi merupakan salah satu penyebab tidak stabilnya perekonomian, sehingga mengharuskan perusahaan untuk mampu mengelola sumberdaya yang dimiliki secara efektif dan efisien. Perlu diingat bahwa dalam era ini, perusahaan bersaing tidak hanya 


\section{Nominal: Barometer Riset Akuntansi dan Manajemen}

P-ISSN: 2303-2065 E-ISSN: 2502-5430

Volume 9 No 1 (2020)

dengan para pesaing lokal tetapi juga para pesaing dari luar negeri. Setiap perusahaan tingkat penjualan menjadi salah satu nilai keberhasilan dari jenis usaha yang bersangkutan. Semakin tinggi tingkat penjualan suatu perusahaan, dengan asumsi besar keuntungan yang didapat sama besar, maka semakin tinggi tingkat laba yang dihasilkan. Salah satu indikator untuk melihat apakah perusahaan tersebut berkembang dengan baik atau tidak secara garis besar adalah dengan melihat banyaknya penjualan yang berhasil dilakukan oleh perusahaan dalam berbagai sektor usaha.

Sektor transportasi merupakan salah satu sektor industri yang sangat dibutuhkan oleh masyarakat dalam menunjang berbagai kegiatan dalam kehidupan. Seiring berjalannya waktu, trasnportasi baru banyak bermunculan, salah satunya dalam sektor transpotrasi udara sedangkan kalau Berbicara mengenai gaya hidup serta kepentingan sosial masyarakat yang semakin hari semakin beragam seperti berlibur, perjalanan bisnis, dalam hal medis, menempuh pendidikan dan lain sebagainya, transportasi udara menjadi salah satu pilihan yang banyak diminati oleh masyarakat asing dan lokal, ini dikarenakan transportasi udara dianggap lebih cepat untuk mengantarkan penunpang ketempat tujuan. Dalam data boks tahun
2019, badan pusat statistik mencatat jumlah penumpang pesawat udara untuk penerbangan domestik pada Oktober 2018 meningkat $6,85 \%$ menjadi 8,11 juta orang dan juga tumbuh 7,85\% dibanding Oktober tahun sebelumnya. Demikian pula secara kumulatif periode Januari-Oktober tahun 2018 tumbuh 6,98\% menjadi 78,63 juta orang dibanding periode yang sama 2017. Sementara jumlah penumpang untuk penerbangan internasional pada Oktober tahun 2018 tumbuh 3,36\% menjadi 1,54 juta orang, namun jika dibanding Oktober tahun lalu tumbuh 14,07\%. Demikian pula secara kumulatif untuk periode JanuariOktober tumbuh $7,8 \%$ menjadi 14,9 juta orang dari periode yang sama tahun lalu 13,84 juta orang. Adanya peningkatan jumlah penumpang menunjukkan tingkat antusias penumpang yang tinggi, berarti sektor transportasi udara dalam hal ini adalah penerbangan nasional mampu memberikan sumbangsih yang positif terhadap pertumbuhan ekonomi nasional. PT Garuda Indonesia Tbk merupakan maskapai penerbangan milik Negara dengan kredibilitas terbaik di mata masyarakat dibandingkan maskapai penerbangan lain. Selain itu merupakan suatu perusahaan go public yang bergerak dalam sektor transportasi udara dan sampai saat ini menjadi satu-satunya maskapai plat 


\section{Nominal: Barometer Riset Akuntansi dan Manajemen}

P-ISSN: 2303-2065 E-ISSN: 2502-5430

Volume 9 No 1 (2020)

merah yang masih eksis dalam dunia penerbangan.

Bagi perusahaan go public maupun non public, Laporan keuangan merupakan catatan informasi yang menunjukkan kondisi keuangan perusahaan pada saat ini atau dalam suatu periode tertentu (Kasmir, 2015). Jika suatu perusahaan menunjukkan kinerja yang kurang baik secara terus menerus, maka perusahaan tersebut mengalami kondisi kesulitan keuangan (financial Distress) yang merupakan gejala atau indikator awal bahwa perusahaan akan berpotensi mengalami kebangkrutan. (Barry, 2019). Kebangkrutan dapat disebabkan oleh 2 faktor yaitu, faktor internal (kinerja perusahaan, kebijakan perusahaan dan budaya perusahaan) dan faktor Eksternal (Kondisi ekonomi, keadaaan politik dan Bencana alam) (Ben, AR, \& Topowijono, 2015).

Dalam lima tahun terakhir, beberapa perusahaan BUMN Indonesia menunjukkan kinerja yang negatif sehingga dikategorikan perusahaan-perusahaan tersebut berpotensi mengalami kebangkrutan. PT Garuda Indonesia (Persero) Tbk merupakan salah satu perusahaan milik negara yang bergerak dalam bidang Jasa Angkutan Udara Niaga. Perusahaan ini sedang ramai diperbincangkan karena menunjukkan kinerja yang menurun selama tahun 2012

sampai 2018 terlihat dari pergerakan harga saham penutup (close) yang terus merosot meskipun sempat meningkat ditahun 2016. Menurut Hanafi Kebangkrutan (bankruptcy) biasanya diartikan sebagai kegagalan perusahaan dalam menajalankan operasi perusahaan untuk menghasilkan laba (Ben et al., 2015). Pihak manajemen PT Garuda Indonesia Tbk memperlihatkan ketidak mampuannya dalam menunjukkan kinerja yang maksimal. Seperti dalam memperoleh profitabilitas, terbukti dari tahun 2012 sampai tahun 2018 keuntungan perusahaan menunjukkankondisi yang berfluktuatif bahkan mengalami kerugian pada tahun 2014, 2017 dan 2018. Oleh karena itu untuk melihat dan mengetahui prospek kedepannya agar dapat meminimalisir terjadinya resiko kebangkrutan dapat dilihat dari perkembangan laba (rugi) dan Pendapatan usaha dari periode 2012-2018 dibawah ini:

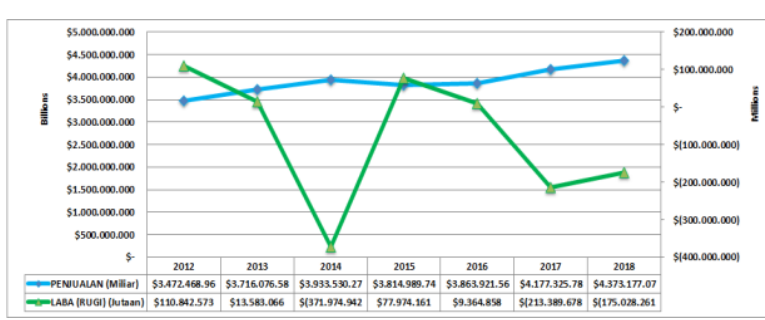

Sumber : Data Sekunder Diolah, 2019. Gambar 1: Grafik Perkembangan Laba (rugi) dan Pendapatan usaha PT Garuda Indonesia TbkTahun 2012-2018

(dalam USD)

Dari gambar diatas dapat dilihat bahwa PT Garuda Indonesia dari Tahun 2012 sampai dengan 2018 menunjukkan 


\section{Nominal: Barometer Riset Akuntansi dan Manajemen}

P-ISSN: 2303-2065 E-ISSN: 2502-5430

Volume 9 No 1 (2020)

perkembangan penjualan dan laba bersih yang berfluktuatif.Selain itu terlihat pada kondisi keuangan dimana terjadinya peningkatan hutang perusahaan secara terus menerus dan perusahaan harus menghadapi peningkatan beban operasional yang terus membengkak (Prihartini \& Sari, 2013)

Penelitian yang dilakukan oleh Barry dengan judul "Prediksi Financial Distress (Kebangkrutan) Pada Perusahaan Ritel Bursa Efek Dengan Model Altman Dan Springate", Menunjukkan hasil dengan model Altman, kempat perusahaan pada tahun 2013-2017 berada pada zona berbahaya kecuali pada perusahan KONI untuk 2013,2014 dan RIMA untuk tahun 2014 berada pada zona Aman. Dengan Motode Springate kempat perusahaan kempat perusahaan pada tahun 2013-2017 perusahaan dikategorikan dalam kondisi kesulitan keuangan dan berpotensi mengalami kebangkrutan. (Barry, 2019) berbeda dengan Penelitian yang dilakukan Ben et al Berdasarkan analisis yang dilakukan, terdapat 8 perusahaan yang masuk dalam kategori perusahaaan tidak berpotensi bangkrut, 9 perusahaan yang masuk dalam kategori yang diprediksi berpotensi bangkrut, 5 perusahaan yang mengalami perubahan kategori dari yang diprediksi berpotensi bangkrut menjadi tidak berpotensi bangkrut, 5 perusahaan yang mengalami perubahan kategori dari tidak berpotensi bangkrut menjadi kategori yang diprediksi berpotensi bangkrut. Menunjukkan hasil pertama terdapat 8 perusahaan yang masuk dalam kategori perusahaan diprediksi tidak berpotensi bangkrut yang memiliki nilai (S-Score) lebih dari 0,862 selama tiga tahun berturutturut dari tahun 2011-2013 (Ben et al., 2015)

Berdasarkan uraian latar belakang diatas, maka dapat dirumuskan permasalahan dalam penelitian ini adalah "Seberapa Besar Prediksi Finanancial Distress Dengan Metode Springate $(S$ Score) Pada PT Garuda Indonesia Tbk?". Adapun tujuan penelitian yang ingin dicapai pada penulisan ini adalah untuk mengetahui besarnya prediksi financial distress dengan metode Springate (S-score) pada PT Garuda Indonesia Tbk.

\section{KAJIAN LITERATUR}

Penelitian ini didasarkan pada beberapa teori sebagai berikut:

\section{Laporan Keuangan}

Menurut Kasmir "Laporan Keuangan merupakan laporan yang menunjukkan kondisi keuangan pada saat ini atau dalam suatu periode tertentu. Tujuan laporan keuangan untuk memberikan informasi tentang kinerja manajemen perusahaan dalam suatu periode guna memenuhi kepentingan 


\section{Nominal: Barometer Riset Akuntansi dan Manajemen}

P-ISSN: 2303-2065 E-ISSN: 2502-5430

Volume 9 No 1 (2020)

berbagai pihak yang berkepentingan terhadap perusahaan. dalam praktiknya secara umum ada lima macam jenis laporan keuangan yaitu: neraca, laporan laba rugi, laporan perubahan modal, dan laporan arus kas. Rasio keuangan merupakan kegiatan membandingkan angka-angka yang ada dalam laporan keuangan dengan cara membagi satu angka dengan angka lainnya. Hasil rasio digunakan untuk menilai kinerja manajemen dalam memberdayakan sumber daya perusahaan secaraefektif pada suatu periode apakah mencapai target seperti yang telah ditetapkan” (Kasmir, 2015).

\section{Financial Distress}

Menurut Plat dan Plat "Financial Distress merupakan tahap penurunan kondisi keuangan sebelum terjadinya kebangkrutan. Kondisi ini bermula ketidakmampuan perusahaan mengelola perusahaan, mengakibatkan kerugian operasional maupun kerugian bersih tahun berjalan dan atau aliran kas operasi yang lebih kecil dibandingkan dengan laba operasinya (Vestari \& Farida, 2014).

\section{Kebangkrutan}

Kebangkrutan (bankruptcy) adalah kegagalan perusahaan dalam menjalankan operasi perusahaan untuk menghasilkan laba (Ben et al., 2015) Menurut Elmabrok, et al kebangkrutan atau kegagalan keuangan yang dialami oleh sebagian besar perusahaan terjadi ketika jumlah kewajiban melebihi nilai wajar aset atau ketika kewajiban lancar melebihi aktiva lancar (Prihartini \& Sari, 2013).

\section{Analisis Kebangkrutan Metode Springate (S-Score)}

Dalam Yunindra (2018) Springate score adalah metode untuk memprediksi kemungkinan kebangkrutan suatu perusahaan. Springate score dihasilkan oleh Gordon L.V Springate pada tahun 1978. Untuk memprediksi adanya potensi (indikasi) kebangkrutanSpringate menggunakan empat rasio dengan (Yunindra, 2018) rumus: $\mathbf{S}=\mathbf{1 . 0 3 X}_{\mathbf{1}}+$ $3.0 X_{2}+0.66 X_{3}+0.4 X_{4}$

Dimana :

a) Rasio modal kerja terhadap total asset $\left(\mathrm{X}_{1}\right)$

Variabel ini digunakan untuk mengukur kemampuan perusahaan dalam memenuhi kewajiban jangka pendeknya dan untuk mengukur tingkat likuiditas aktiva perusahaan. Dengan rumus :

$$
\begin{aligned}
& \mathrm{X}_{1} \\
& =\frac{\text { Aset Lancar }- \text { Liabilitas Lancar }}{\text { Total Aset }}
\end{aligned}
$$

Sumber : (Yunindra, 2018)

b) Rasio laba sebelum bunga dan pajak terhadap total aset $\left(\mathrm{X}_{2}\right)$

Dalam rasio profitabilitas yang memiliki fungsi untuk mengukur kemampuan perusahaan dalam menghasilkan laba dari 
aktiva yang digunakan atau dapat dikatakan sebagai ukuran produktifitas asset perusahaan. Mengukur kemampuan perusahaan untuk menghasilkan laba. Dengan rumus:

$$
\mathrm{X}_{2}=\frac{\text { EBIT }}{\text { Total Aset }}
$$

Sumber : (Yunindra, 2018)

c) Rasio laba sebelum Pajak terhadap total Liabilitas Lancar $\left(\mathrm{X}_{3}\right)$

Ebit to Current Liabilities digunakan untuk mengukur kemampuan perusahaan dalam melunasi hutang jangka pendeknya. Rasio EBT terhadap liabilitas lancar agar perusahaan dapat mengetahui berapa laba yang telah dipotong dengan beban bunga dapat menutupi hutang lancar yang ada. Dengan rumus:

$$
\mathrm{X}_{3}=\frac{\text { Laba SebelumPajak }}{\text { Liabilitas Lancar }}
$$

Sumber :(Yunindra, 2018)

d) Rasio penjualan terhadap total Aset $\left(\mathrm{X}_{4}\right)$

Total Asset Turn Over (X4) merupakan Rasio yang menunjukkan tingkat efisiensi penggunaan keseluruhan aktiva perusahaan dalam menghasilkan penjualan. Rasio ini mengukur seberapa efisien aktiva tersebut telah dimanfaatkan untuk memperoleh penghasilan. Semakin tinggi Total Asset Turn Over berarti semakin efisien penggunaan keseluruhan aktiva perusahaan dalam menghasilkan volume penjualan. Dengan rumus :

$$
\mathrm{X}_{4}=\frac{\text { Penjualan }}{\text { Total Aset }}
$$

Sumber : (Yunindra, 2018)

Menurut Gordon L.V Springate Kriteria Penilaian Model Springate Score (S-Sore) merupakan penilaian keberlangsungan hidup perusahaan diklasifikasikan (Yunindra, 2018) :

- $\mathrm{Z}>0,862$ dikategorikan sebagai perusahaan sehat

- $\mathrm{Z}<0,862$ dikategorikan sebagai perusahaan dalam kondisi financial distressdan berpotensi mengalami kebangkrutan.

\section{Penelitian Terdahulu}

Penelitian yang dilakukan oleh Husnil Barry, dengan judul "Prediksi Financial Distress (Kebangkrutan) Pada Perusahaan Ritel Bursa Efek Dengan Model Altman Dan Springate”, (2019). Menunjukkan hasil dengan model Altman, kempat perusahaan pada tahun 2013-2017 berada pada zona berbahaya kecuali pada perusahan KONI untuk 2013,2014 dan RIMA untuk tahun 2014 berada pada zona Aman. Dengan Motode Springate kempat perusahaan kempat perusahaan pada tahun 2013-2017 perusahaan dikategorikan dalam kondisi kesulitan keuangan dan berpotensi mengalami kebangkrutan.

Penelitian yang dilakukan oleh $\mathrm{Ni}$ Made Evi Dwi Prihantini dan Maria M. Ratna Sari, dengan judul Prediksi 
Kebangkrutan Dengan Model Grover, Altman-Zscore, Springate dan Zmijewski Pada Perusahaan Food And Beverage Di Bursa Efek Indonesia” (2013). Menunjukkan hasil Pertama bahwa terdapat perbedaan antara model Grover dengan Model Altman Z-Score, Model Grover dengan Model Springate, dan model Grover dengan model Zmijewski dalam memprediksi kebangkrutan pada perusahaan Food And Beverage yang terdaftar di Bursa Efek Indonesia (BEI). Selain itu hasil kedua bahwa model Grover merupakan model prediksi yang paling sesuai diterapkan pada perusahaan Food And Beverage yang terdaftar di Bursa Efek Indonesia (BEI) karena model ini memiliki tingkat keakuratan yang paling tinggi dibandingkan model lainnya yaitu sebesar 100\%. sedangkan model Altman Z-Score memiliki tingkat akurasi sebesar $80 \%$, model Springate $90 \%$ dan Model Zmijewski 90\%.

Penelitian yang dilakukan oleh Ditiro Alam Ben, Moch. Dzulkirom AR, Topowijono dengan judul "Analisis Metode Springate (S-Score) Sebagai Alat Untuk Memprediksi Kebangkrutan Perusahaan", (2015). Menunjukkan hasil pertama terdapat 8 perusahaan yang masuk dalam kategori perusahaan diprediksi tidak berpotensi bangkrut yang memiliki nilai (SScore) lebih dari 0,862 selama tiga tahun berturut-turut dari tahun 2011-2013. 9 perusahaan masuk dalam kategori perusahaan yang diprediksi berpotensi bangkrut memiliki nilai (S-Score) kurang dari 0,862 selama tiga tahun berturut-turut yaitu tahun 2011-2013. Kemudian terdapat 5 perusahaan yang mengalami perubahan kategori dari perusahaan dari perusahaan berpotensi bangkrut menjadi perusahaan yang dikategorikan tidak berpotensi bangkrut. Dan terdapat 5 perusahaan yang mengalami perubahan kategori perusahaan yang diprediksi berpotensi tidak bangkrut menjadi berpotensi bangkrut. Kemudian menunjukkan Hasil kedua yaitu dari keempat rasio dalam metode Springate yang berpengaruh secara partial terhadap prediksi kebangkrutan yaitu modal kerja terhadap total aset berpengaruh paling besar. Lalu menunjukkan hasil ketiga dari keempat rasio sebagai variabel independen berpengaruh secara simultan terhadap prediksi kebangkrutan.

Penelitian yang dilakukan oleh Andri Eka Yunindra dengan judul "Analisa Rasio Keuangan Dalam Memprediksi Kebangkrutan Perusahaan Industri Sub Sektor Textile Dan Garment Yang Terdaftar Di Bursa Efek Indonesia", (2018). Menunjukkan hasil bahwa perusahaan Textile Dan Garment Yang Terdaftar Di Bursa Efek Indonesia dalam penelitian ini mengalami fluktuatif dimana 
selama periode akhir penelitian diprediksi mengalami potensi kebangkrutan.

Meskipun hasil peneltian-penelitian diatas berbeda pada jenis penelitian dan objek penelitian yang dilakukan peneliti, namun penelitian-penelitian tersebut dapat dijadikan acuan penulis serta pentingnya untuk memprediksi lebih awal dalam mendeteksi muncul gejala financial distress pada suatu perusahaan sehingga perusahaan dapat bersiaga dalam menetapkan langkahlangkah dalam menghindari terjadinya kebangkrutan yang sebenarnya

\section{Kerangka Pikir}

PT Garuda Indonesia Tbk adalah salah satu perusahaan go public yang bergerak pada sektor transpotasi udara yang menjadi salah satu perusahaan BUMN terbesar dan masih mempertahankan esksistensinya hingga saat ini. Dalam hal untuk mempertahankan keberadaannya agar tidak kalah dalam persaingan bisnis, perusahaan harus mampu mengelola sumber daya yang dimiliki seefisien dan seefektif mungkin agar mampu memperoleh kinerja yang positif secara terus menerus sehingga terhindar dari kesulitan keuangan atau bahkan kebangkrutan. Namun jika suatu perusahaan tersebut menunjukkan kinerja yang negatif maka perusahaan harus segera mungkin mendeteksi keadaan tersebut dengan metode prediksi kebangkrutan salah satunya adalah Springate score. Hasil Springate score $>0,862$ maka perusahaan dikatakan dalam kondisi yang sehat namun jika Springate score $<0,862$ maka perusahaan dalamdalam kondisi financial distress dan berpotensi mengalami kebangkrutan. Adapun kerangka pikir dalam penelitian ini disajikan pada gambar 2.

\section{Hipotesis}

$\mathrm{H}_{\mathrm{o}}: \mu \leq 0,862$, Springate Score (S-Score) Pada PT Garuda Indonesia Tbk kurang dari 0,862 dari yang diharapkan (Perusahaan dikategorikan dalam kondisi financial distress dan berpotensi mengalami kebangkrutan).

$\mathrm{H}_{\mathrm{o}}: \mu>0,862$, Springate Score (S-Score) Pada PT Garuda Indonesia Tbk lebih dari 0,862 dari yang diharapkan (Perusahaan dikategorikan tidak dalam kondisi financial distress dan berpotensi mengalami kebangkrutan).

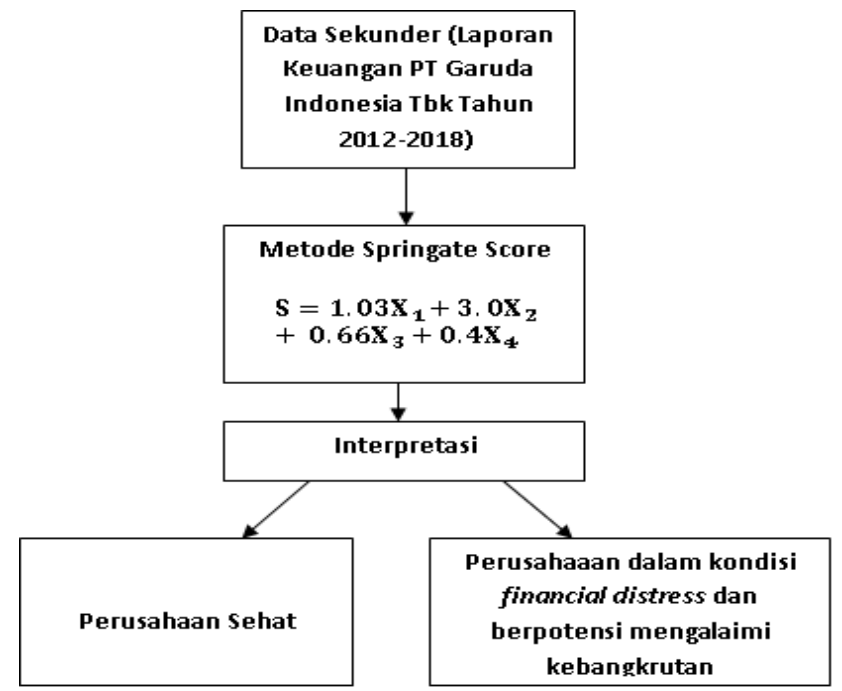

Gambar 2 Kerangka Pikir 


\section{METODE PENELITIAN}

\section{Jenis Penelitian}

Jenis Penelitian ini merupakan penelitian deskriptif yaitu penelitian yang dilakukan untuk mengetahui nilai variable mandiri, (Sugiyono, 2010). dengan Metode Penelitian kuantitatif. Maksud penulis menggunakan metode penelitian deskriptif adalah untuk mendeskripsikan prediksi financial distress dengan metode Springate score (S-Score) pada PT Garuda Indonesia Tbk. Metode.

\section{Tempat dan Waktu Penelitian}

Penelitian ini dilakukan dengan mengambil data sekunder PT Garuda Indonesia Tbk yang terdaftar di Bursa Efek Indonesia. Data yang digunakan diperoleh dari website resmi BEI www.idx.co.id. Pengumpulan dan pengolahan data telah dilaksanakan bulan Oktober 2019 hingga bulan Januari tahun 2020.

\section{Subyek Penelitian}

Populasi adalah wilayah generalisasi yang terdiri atas: obyek/subyek yang mempunyai kualitas dan karakteristik tertentu yang ditetapkan oleh peneliti untuk dipelajari dan kemudian ditarik kesimpulannya (Sugiyono, 2016). Populasi dalam penelitian ini adalah laporan keuangan PT Garuda Indonesia yang diakses melalui website www.idx.co.id dalam bentuk neraca(posisi keuangan) yang terdiri atas data aset lancar, liabilitas lancar, total aset,dan laba rugi yang terdiri atas data laba sebelum bunga dan pajak, laba sebelum pajak dan penjualanselama delapan tahun terakhir yaitu dari tahun 2011 sampai dengan 2018.

Sampel adalah bagian dari jumlah dan karakteristik yang dimiliki oleh populasi tersebut (Sugiyono, 2016) Sampel yang digunakan dalam penelitian ini adalah laporan keuangan pada PT Garuda Indonesia Tbk dalam bentuk neraca (posisi keuangan), yang terdiri atas data aset lancar, liabilitas lancar, total aset,dan laporan laba rugi yang terdiri atas data laba sebelum bunga dan pajak, laba sebelum pajak dan penjualanselama tujuh tahun terakhir yaitu dari tahun 2012 sampai dengan 2018. Teknik sampling yang digunakan yaitu sampling purposive. Sampling Purposive adalah teknik penentuan sampel dengan pertimbangan tertentu. Adapun pertimbangan yang dilakukan penulis adalah terletak pada ketersediaan data dan penggunaan data yang masih baru (update) (Sugiyono, 2016).

\section{Teknik Pengumpulan Data}

Instrumen dalam penelitian yang digunakan dalam penelitian ini adalah laporan keuangan berupa daftar 53 arif dalam bentuk laporan neraca (posisi 


\section{Nominal: Barometer Riset Akuntansi dan Manajemen}

P-ISSN: 2303-2065 E-ISSN: 2502-5430

Volume 9 No 1 (2020)

keuangan) yang terdiri atas data aset lancar, liabilitas lancar, total aset,dan laporan laba rugi yang terdiri atas data laba sebelum bunga dan pajak, laba sebelum pajak dan penjualan selama tujuh tahun terakhir yaitu dari tahun 2012 sampai dengan 2018. Teknik pengumpulan data yang digunakan penulis dalam penelitian ini adalah dokumentasi yaitu mencari data mengenai hal-hal yang berkaitan dengan penelitian yang dibahas berupa catatan, transkrip,buku, jurnal-jurnal terdahulu dan sebagainya. Didalam melaksanakan metode dokumentasi ini, peneliti mengumpulkan data dokumentasi berupa laporan keuangan PT Garuda Indonesia Tbk Periode tahun 2012-2018.Selain itu teknik pengumpulan data yang digunakan berupa studi pustaka, yaitu dilakukan dengan cara mempelajari literatur-literatur serta pendapat para ahli yang ada relevansi dengan judul penelitian ini.

\section{Teknik Analisis Data}

Teknik analisis data yang digunakan dalam penelitian ini adalah sebagai berikut:

\section{Analisis Kebangkrutan Dengan Metode \\ Springate (S-Score)}

Springate score adalah metode untuk memprediksi kemungkinan kebangkrutan suatu perusahaan.

Springate score dihasilkan oleh Gordon L.V Springate pada tahun 1978. Untuk memprediksi adanya potensi (indikasi) kebangkrutan. Springate menggunakan empat rasio (Yunindra, 2018) : Dengan rumus $S=1.03 X_{1}+3.0 X_{2}+0.66 X_{3}+$ $0.4 X_{4}$

Dimana:

Rasio modal kerja terhadap total asset $\left(\mathrm{X}_{1}\right)$

$\mathrm{X}_{1}=\frac{\text { Aset lancar }- \text { Liabilitas Lancar }}{\text { Total Aset }}$

Rasio Laba Sebelum Bunga Dan Pajak

Terhadap Total Aset $\left(\mathrm{X}_{2}\right)$

$$
\mathrm{X}_{2}=\frac{\text { EBIT }}{\text { Total Aset }}
$$

Rasio Laba Sebelum Pajak Terhadap Total Liabilitas Lancar $\left(\mathrm{X}_{3}\right)$

$$
\mathrm{X}_{3}=\frac{\text { Laba Sebelum Pajak }}{\text { Liabilitas Lancar }}
$$

Rasio Penjualan Terhadaptotal Aset $\left(\mathrm{X}_{4}\right)$

$$
\mathrm{X}_{4}=\frac{\text { Penjualan }}{\text { Total Aset }}
$$

Menurut Gordon L.V springate dengan kriteria penilaian model Springate score ( $s$ sore) merupakan penilaian keberlangsungan hidup perusahaan diklasifikasikan (Barry, 2019):

- $\mathrm{Z}>0,862$ dikategorikan sebagai perusahaan sehat.

- $\mathrm{Z}<0,862$ dikategorikan sebagai perusahaan dalam kondisi financial distressdan berpotensi mengalami kebangkrutan.

\section{Analisis Pengujian Hipotesis}

Untuk menguji hipotesis tersebut maka digunakan ujit-test one sampel 
dengan rumus sebagai berikut (Sugiyono, 2016) :

$$
t=\frac{\bar{X}-\mu_{o}}{s / \sqrt{n}}
$$

Dimana:

$\mathrm{t}=$ Nilai $\mathrm{t}$-hitung

$\bar{X}=$ Nilai rata-rata

$\mu_{o} \quad=$ Nilai yang dihipotesiskan

$\mathrm{s} \quad=$ Simpangan baku sampel

$\mathrm{n} \quad=$ Jumlah sampel

Dengan ketentuan bila $t_{\text {hitung }}$ lebih besar dari $t_{\text {tabel }}$ dengan taraf signifikansi 5\% ( $\left.\mathrm{t}_{\text {hitung }}>\mathrm{t}_{\text {tabel }}\right)$, maka Ha diterima Ho ditolak, sebaliknya jika thitung lebih kecil dari table $\left(t_{\text {hitung }}<t_{\text {tabel }}\right)$ maka Ho diterima dan $\mathrm{Ha}$ ditolak.

\section{HASIL PENELITIAN DAN PEMBAHASAN}

\section{Deskripsi Data Penelitian}

Data yang digunakan dalam penelitian ini merupakan data sekunder eksternal berupa laporan keuangan auditan PT Garuda Indonesia Tbk yang diperoleh melalui website www.idx.co.id. Sampel yang dipilih menggunakan teknik purposive sampling yaitu laporan keuangan auditan selama tujuh tahun terakhir yaitu dari tahun 2012 sampai dengan 2018.

\section{Analisis Kebangkrutan Dengan Metode Springate Score (S-Score)}

Pada Tahun 2012 S-score diperoleh sebesar 0,841 walaupun nilai menunjukkan tidak terlalu jauh dari nilai kriteria yang

ditetapkan namun dapat diklasifikasikan, perusahaan mengalami kondisi financial distress dan berpotensi mengalami kebangkrutan. Hal ini disebabkan oleh modal kerja pada perusahaan yang negatif yang artinya perusahaan dihadapkan pada kondisi yang kesulitan dalam memenuhi kewajiban lancarnya. Tidak hanya itu peninggkatan total liabilitas perusahaan yang dikarenakan perusahaan melakukan ekpansi armada untuk memenuhi pertumbuhan pasar selain itu perusahaan dihadapkan pula pada peningkatan beban usaha perusahaan seperti kenaikan bahan bakar pesawat dan meningkatnya beban layanan penumpang dikarenakan jumlah penumpang yang meningkat.

Tabel 1 Hasil Interpretasi Nilai Springate Pada PT Garuda Indonesia Tbk 2012-2018

\begin{tabular}{ccc}
\hline Tahun & S-score & Keterangan \\
\hline 2012 & 0,841 & Berpotensi Bangkrut \\
2013 & 0,526 & Berpotensi Bangkrut \\
2014 & $-0,273$ & Berpotensi Bangkrut \\
2015 & 0,618 & Berpotensi Bangkrut \\
2016 & 0,393 & Berpotensi Bangkrut \\
2017 & 0,072 & Berpotensi Bangkrut \\
2018 & $-0,176$ & Berpotensi Bangkrut \\
\hline \multicolumn{2}{c}{ Sumber : Data Sekunder diolah,2019 }
\end{tabular}

Tabel 2 Modal Kerja PT Garuda Indonesia Tbk

\begin{tabular}{cr}
\hline TAHUN & MODAL KERJA \\
\hline 2012 & -117.640 .834 \\
2013 & -164.756 .844 \\
2014 & -408.850 .413 \\
2015 & -188.001 .116 \\
2016 & -398.442 .819 \\
2017 & -935.104 .520 \\
2018 & -1.883 .433 .695 \\
\hline
\end{tabular}


Tabel 3 Beban Usaha dan Total liabilitas PT

Garuda Indonesia Tbk (Dalam satuan USD)

\begin{tabular}{ccc}
\hline TAHUN & Beban Usaha & Total Liabilitas \\
\hline 2012 & 3.304 .396 .858 & 1.403 .037 .688 \\
2013 & 3.659 .628 .311 & 1.836 .636 .835 \\
2014 & 4.332 .843 .278 & 2.184 .103 .458 \\
2015 & 3.731 .785 .485 & 2.359 .287 .801 \\
2016 & 3.795 .927 .643 & 2.727 .672 .171 \\
2017 & 4.237 .773 .332 & 2.825 .822 .893 \\
2018 & 4.579 .259 .674 & 3.437 .474 .497 \\
\hline \multicolumn{3}{c}{ Sumber: Data Sekunder diolah, 2019 }
\end{tabular}

Pada tahun 2013 S-Score diperoleh sebesar 0,526 menunjukkan penurunan sebesar 0,315 dibandingkan tahun 2012 namun menurut kriteria yang ditetapkan perusahaan diklasifikasikan mengalami kondisi financial distress dan berpotensi mengalami kebangkrutan. Hal ini disebabkan oleh modal kerja perusahaan masih menunjukkan nilai yang negatif yang artinya kondisi likuiditas perusahaan rendah. (Fredy, 2018)

Selain itu, total kewajiban perusahaan kembali meningkat dibandingkan tahun 2012. Pertumbuhan pendapatan usaha perusahaan mengalami kenaikan dikarenakan sumbangsih penerbangan berjadwal namun pada penerbangan tidak berjadwal kurang maksimal dikarenakan adanya kebijakan yang pembatasan kuota haji oleh pemerintah Arab Saudi, sehingga laba bersih perusahaan mengalami penurunan dibandingkan tahun 2012. Walupun perusahaan berhasil melakukan upaya efisiensi bahan bakar melalui pemanfaatan armada yang lebih efisien namun beban usaha ditahun 2013 tetap meningkat dibandingkan tahun 2012.

Pada tahun 2014 S-score yang diperoleh sebesar -0,273 menunjukkan penurunan yang drastis sebesar 0,799 bahkan berada pada nilai yang negatif. Sehingga dapat diklasifikasikan, perusahaan mengalami kondisi financial distress dan berpotensi mengalami kebangkrutan. Hal ini disebabkan oleh modal kerja perusahaan yang terus menunjukkan angka yang negatif. Selain total kewajiban yang meningkat ditahun 2014. Pendapatan usaha yang diperoleh perusahaan memang menunjukan peningkatan dibandingkan tahun 2013 walaupun tidak terlalu jauh selisihnya dibandingan tahun 2013, peningkatan ini terutama berasal dari penerbangan berjadwal namun, perusahaan justru mengalami kerugian.Hal ini dipengaruhi perusahaan harus dihadapakan pada peningkatan beban usaha operasioanal yang berasal dari banyak aspek, salah satunya aspek terbesarnya yaitu harga bahan bakar avtur dunia yang terus meningkat padahal perusahaan sudah melakukan kebijakan efisiensi bahan bakar melalui pemanfaatan armada yang lebih efisien dan menaikkan tarif harga tiket penumpang namun masih belum mampu menutupi beban perusahaan. 
Pada tahun 2015 S-score diperoleh 0,618 menunjukkan peningkatan sebesar 0,345 dibandingkan pada tahun 2014. Namun peningkatan tersebut tidak mengubah perusahaan masih diklasifikasikan mengalami kondisi financial distress dan berpotensi mengalami kebangkrutan. Hal ini disebabkan oleh modal kerja perusahaan yang terus menunjukkan angka yang negatif. Selain itu faktor lainnya pada tahun 2015 posisi pendapatan usaha yang diperoleh perusahaan mengalami penurunan dibandingkan tahun 2014 dikarenakan turunnya pendapatan pada penerbangan berjadwal. Namun ditahun 2015 ini justru perusahaan berhasil memperoleh laba bersih dibandingkan tahun 2014 yang mengalami kerugian. Hal ini dikarenakan strategi pengembangan bisnis yang dilakukan perseroan melalui program Quick Winsserta keberhasilan perseroan menekan beban perusahaan yang menurun dibandingkan tahun 2014 akibat menurunnya harga bahan bakar avtur dunia.

Pada tahun 2016 S-score diperoleh 0,393 menunjukkan penurunan sebesar 0.225 dibandingkan tahun 2015, sehingga perusahaan masih diklasifikasikan dalam kondisi financial distress dan berpotensi mengalami kebangkrutan. Hal ini disebabkan oleh modal kerja perusahaan yang terus menunjukkan angka yang negatif. Pendapatan usaha yang diperoleh perusahaan justru memperlihtkan peningkatan dibandingkan tahun 2015 dikarenakan meningkatnya pendaptan penerbangan berjadwal dan pendapatan lain-lain. Namun pada laba sebelum bunga dan pajak serta laba bersih perusahaan justru mengalami penurunan dibandingkan tahun 2015 hal ini dikarenakan tingginya biaya investasi, menurunnya daya beli masyarakat dan terjadinya bencana alam seperti erupsi, banjir, longsor yang terjadi dibeberapa wilayah indonesia yang mengakibatkan kinerja perusahaan kurang maksimal disebabkan menurunnya minat konsumen menggunakan jasa penerbanganb atau konsumen menunda penerbangan atau membatalkan penerbangan. Selain itu perusahaan masih dihadapakan dengan peningkatan total kewajiban perusahaan setiap tahunnya. Walaupun harga bahan bakar avtur pesawat menurun, perusahaan harus menanggung beban usaha yang meningkat kembali dibandingkan tahun 2015 akibat peningkatan biaya perbaikan dan pemeliharaan pesawat seiring penambahan armada dan beban bandara.

Pada tahun 2017 S-score diperoleh 0,072 menunjukkan penuruan sebesar 0,321 dibandingkan tahun 2016, perusahaan masih diklasifikasikan dalam kondisi financial distress dan berpotensi 


\section{Nominal: Barometer Riset Akuntansi dan Manajemen}

P-ISSN: 2303-2065 E-ISSN: 2502-5430

Volume 9 No 1 (2020)

mengalami kebangkrutan. Hal ini disebabkan oleh modal kerja perusahaan yang terus menunjukkan angka yang negatif. Perusahaan berhasil meningkatkan pendapatan usaha dibandingkan tahun 2016 hal ini disebabkan oleh kontribusi positif pada penerbangan haji dan charter serta kontribusi pendapatan lain-lain dari anak perusahaan. namun hal ini tidak mendukung perusahaan dalam memperoleh keuntungan justru berada pada posisi perusahaan mengalami kerugian dikarenakan perusahaan harus menanggung biaya operasioanal yang tinggi seperti kenaikan baban umum administrasi, beban transportasi, beban bandara, beban operasional penerbangan, serta beban pemeliharaan dan perbaikan. Beban tersebut banyak dikeluarkan terkait ekpansi yang dilakukan. Selain itu perusahaan melakukan transaksi luar biasa yang terjadi pada tahun 2017 seperti biaya pengampunan pajak dan denda kontijensi kartel kargo. Hal tersebut telah membuat kinerja perseroan menurun ditahun 2017.

Pada tahun 2018 S-score diperoleh 0,176 menunjukkan penurunan sebesar 0,248 dibandingkan tahun 2017 bahkan menunjukkan nilai yang negatifperusahaan masih diklasifikasikan dalam kondisi financial distress dan berpotensi mengalami kebangkrutan. Hal ini disebabkan oleh modal kerja perusahaan yang terus menunjukkan angka yang negatif, oleh karena itu perusahaan dihadapkan pada posisi likuiditas perusahaan yang rendah. Perusahaan masih dihadapkan pada tahun 2017 terjadinya peningkatan total kewajiban setiap tahunnya. Pendapatan usaha perusahaan meningkat namun tidak dengan perolehan laba yang justru perusahaan mengalami kerugian yang meningkat dibandingkan tahun 2018. Hal ini disebakan oleh tinggi tingkat beban usaha yang terletak pada kenaikan harga bahan bakar avtur dunia selain itu perusahaan tingginya beban jasa layanan penumpang sehingga beban operasional melebihi pendapatan usaha yang diperoleh perusahaan.

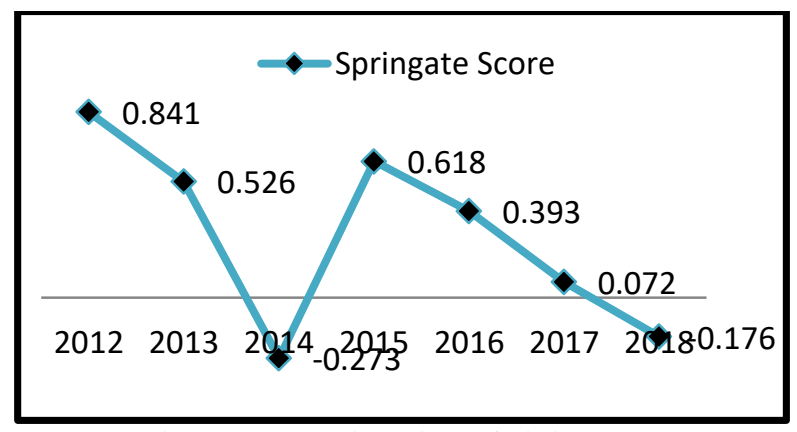

Sumber: Data Sekunder Diolah, 2019. Gambar 3 Grafik Nilai Springate Periode 2012-2018

Hasil pengklasifikasian melalui metode Springate Score yang terlihat pada grafik diatas, kinerja PT Garuda Indonesia Tbk sebagai salah satu perusahaan plat merah transportasi udara Indonesia selama tujuh tahun terakhir yaitu dari tahun 2012 sampai dengan 2018 menunjukkan nilai kurang dari kriteria yang ditetapkan yaitu 


\section{Nominal: Barometer Riset Akuntansi dan Manajemen}

P-ISSN: 2303-2065 E-ISSN: 2502-5430

Volume 9 No 1 (2020)

sebesar 0,862 sehingga perusahaan dikategorikan mengalami kondisi financial distress dan berpotensi mengalami kebangkrutan. Hal ini disebabkan oleh berbagai faktor baik faktor internal perusahaan seperti tingginya beban operasioanal yang ditanggung perusahaan, perusahaan memperoleh laba yang berfluktuatif bahkan perusahaan mengalami kerugian pada tahun 2014, 2017, dan 2018. Selain itu perusahaan menanggung total kewajiban perusahaan yang meningkat secara terus menerus, hal-hal tersebut muncul karena dilakukannya program perluasan ekpansi dan pengembangan ruterute baru dengan menambah jumlah armada perusahaan. Dalam CCN Indonesia wakil ketua KPK Laode M. Syarif mengungkapkan salah satu hal yang membuat PT Garuda Indonesia mengalami performa kinerja yang tidak stabil dan bahkan merugi dikarenakan kurang maksimalnya pengelolaan dalam hal manajemen bagi pihak-pihak yang ada dalam perusahaan.

Faktor eksternal perusahaan memberikan andil pula bagi performa perusahaan yang kurang maksimal yaitu depresiasi Rupiah terhadap Dolar AS sangat berpengaruh pada performa keuangan, mengingat sebagian besar rute Garuda Indonesia memberikan pendapatan dalam Rupiah sedangkan pembiayaan hampir didominasi dalam Dolar AS. Selain itu semakin ketatnya persaingan diwilayah domestik dan regional terkait dengan dengan gencarnya pertumbuhan LCC (Low Cost Carrier). Meningkatnya pula persaingan dikawasan internasional, perubahan peraturan kebijakan baik dalam negeri maupun luar negeri, selain itu adanya force majeure seperti bencana erupsi gunung berapi, banjir, gempa dan tsunami dibeberapa penerbangan domestik wilayah Indonesia. Selain tu melemahnya tingkat daya beli masyarakat memberikan gambaran akan semakin ketatnya persaingan operator penerbangan di Indonesia untuk memikat masyarakat dalam memilih penggunaan suatu produk penerbangan yang mengakibatkan tidak tercapainya target yang telah ditetapkan perusahaan.

\section{Analisis Pengujian Hipotesis}

One sampel t-test didapatkan nilai $\mathrm{t}_{\text {hitung }}$ lebih kecil dari pada $\mathrm{t}_{\text {tabel }}$ ($3.628<1.943)$. sehingga hipotesis Ho yang berbunyi Sprigate Score (S-Score) pada PT Garuda Indonesia Tbk kurang dari 0.862 dari yang diharapkan diterima yang artinyaperusahaan dikategorikan dalam kondisi financial distress dan berpotensi mengalami kebangkrutan. 
Tabel 4 Nilai t hitungOne Sampel Test

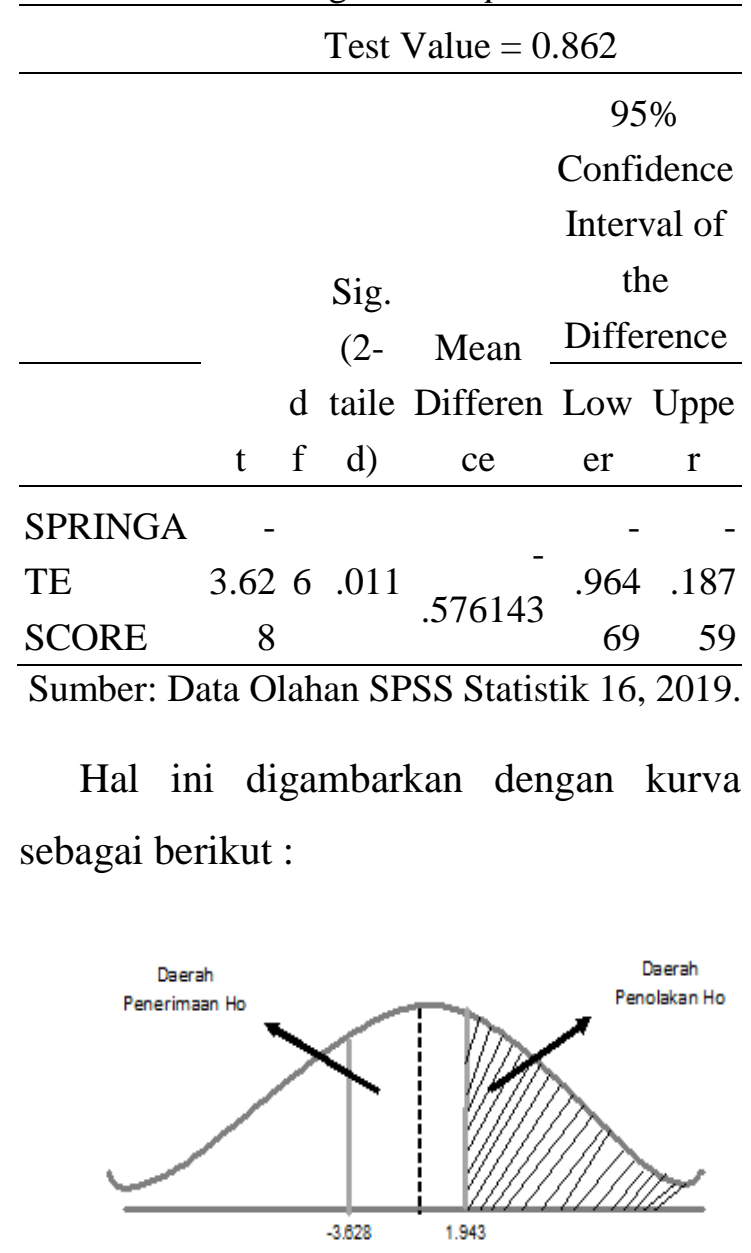

Gambar 4 Kurva Uji Hipotesis Pihak Kanan

Berdasarkan hasil diatas maka nilai t hitung untuk variabel Springate Score adalah sebesar $-3,628$ kemudian nilai $t$ hitung tersebut akan dibandingkan dengan $\mathrm{t}$ tabel dengan derajat kebebasan $(\mathrm{dk})=\mathrm{n}-1$ 7-1=6 dan taraf kesalahan 5\% (0.05) untuk uji satu pihak (one tail test) pihak kanan didapat $t_{\text {tabel }}$ (pada tabel daftar distribusi tabel) adalah sebesar 1,934.

\section{SIMPULAN DAN SARAN}

\section{Simpulan}

Berdasarkan hasil analisa dan pembahasan, maka dapat disimpulkan bahwa PT Garuda Indonesia Tbk dikategorikan dalam kondisi financial distress dan berpotensi mengalami kebangkrutan. Dari sisi pengelolaan modal kerja yang dilakukan PT Garuda Indonesia Tbk belum maksimal atau dapat dikatakan belum mampu mengelolanya secara efisien, hal ini terbukti bahwa perhitungan dengan motode Springate modal kerja perusahaan menunjukkan angka yang negatif secara terus menerus selama tujuh tahun. Tingginya total kewajiban yang tidak sebanding dengan pengelolaan aset membuat modal kerja menunjukkan nilai yang negatif. Hal ini yang dapat juga mempengaruhi kondisi keuangan perusahaan lainnya seperti dalam perolehan laba sebelum pajak terhadap total aset. Tingginya beban operasioanal perusahaan tanpa diimbangi tingginya pendapatan usaha membuat ketidakstabilan kinerja PT Garuda Indonesia harus dilakukan pembenahan baik secara internal dan eksternal secepat mungkin dilakukan, baik dalam menghadapi kondisi depresiasi pertukaran Rupiah terhadap Dollar, tingginya pesaingan baik domestik dan internasional, atapun dalam perencanaan strategi seperti dalam ekspansi dengan melakukan penambahan armada melalui pembelian pesawat dan pemilihan rute penerbangan yang mampu memberikan 
kontrubusi positif dalam perolehan keuntungan bagi perusahaan.

Perubahan dalam sistem jajaran direksi perlu dilakukan, untuk menghindari permasalahan dalam ketidakmampuan sdm dalam mengelola perseroan. Ketidakmampuan inilah yang berakibat pada fluktuatifnya profitabilitas yang dihasilkan perusahaan bahkan mengalami kerugian pada tahun 2014, 2017 dan 2018. Langkah-langkah perbaikan dalam bidang sumber daya, bidang keuangan harus dilakukan dengan segera mungkin, karena jika pengelolaan tetap pada pola yang sama maka ditakutkan kebangkrutan yang sebenarnya dapat terjadi pada Perusahaan.

\section{Saran}

Berdasarkan kesimpulan yang telah dikemukakan:

- Pihak manajemen lebih memperhatikan kegiatan operasionalnya lagi misalnya, menangguhkan atau menunda pembelian pesawat baru karena mengingat tingginya total kewajiban perusahaan yang terus meningkat yang tidak mampu ditanggulangi oleh perusahaan.

- Melakukan perbaikan dalam jajaran sumber daya manusia sebagai tenaga kerja dalam perusahaan, dengan cara lebih selektif dalam perekrutan karyawan serta melakukan perubahan dan penggantian jajaran pengurus perusahaan sehingga mampu menciptakan kebijakan yang tepat bukan malah kebijakan yang dapat merugikan baik dari segi citra perusahaan maupun segi financial perusahaan.

- Mempertimbangkan secara matang dalam melihat rute-rute domestik yang mampu memberikan kontribusi positif dalam memperoleh profitabilitas.

- Meningkatkan dan mempertahankan safety penerbangan, pelayanan pada konsumen, serta keberagaman produk sehingga konsumen tidak ragu dalam menggunakan jasa penerbangan Garuda walaupun dengan tarif tiket yang mahal.

\section{Keterbatasan Penelitian}

Dalam penelitian ini peneliti memiliki beberapa keterbatasan diantaranya:

- Penelitian ini hanya menggunakan variabel rasio keuangan yang digunakan dalam metode Springate

- Penelitian ini hanya menggunakan satu objek penelitian yaitu PT Garuda Indonesi Tbk dengan Sampel penelitian yang dilakukan yaitu laporan keuangan perusahaan selama tujuh tahun terakhir yaitu 2012 sampai dengan 2018 dengan teknik sampling Purposive Sampling.

- Penelitian ini hanyalah bersifat "prediksi" atau dengan kata lain perkiraan atau forecastingsehingga 
nilai "S" yang ada dalam penelitian ini tidak bisa dijadikan tolak ukur dalam penentuan apakah perusahaan tersebut akan benar-benar bangkrut ataupun tidak bangkrut, karena masih banyak indikator-indikator yang harus diperhatikan oleh manajemen sebagai penyebab kegagalan suatu perusahaan. salain itu variabel keempat rasio dalam metode Springate ini diperoleh dari laporan keuangan yang telah diaudit sehingga jika terjadi kesalahan penyusunan dalam laporan keuangan tersebut maka S-Score tidak akan akurat.

\section{DAFTAR PUSTAKA}

Barry, H. (2019). Prediksi Model Financial Distress (Kebangkrutan) Pada Perusahaan Ritel Efek Dengan Model Altman dan Springate Indonesia Periode 2012-2016. Jurnal Ekonomi Dan Bisnis, 6(1), 941-947.

Ben, D. A., AR, M. D., \& Topowijono. (2015). Analisis Metode Springate (SScore) Sebagai Alat Untuk Memprediksi Kebangkrutan Perusahaan (Studi Pada Perusahaan Property dan Real Estate yang Listing di Bursa Efek Indonesia pada Tahun 2011-2013). Jurnal Administrasi Bisnis S1 Universitas Brawijaya, 21(1), 85770.

Fredy, H. (2018). The Prediction of Bankruptcy in the Pulp and Paper Industry Company Listed in Indonesia Stock Exchange on 2011-2016 Period Using Z-Score. South East Asia Journal Of Contemporary Business,
Economics and Law, 15(5), 52-62.

Kasmir. (2015). Analisis Laporan Keuangan. Jakarta: Rajawali Pers.

Prihartini, N. M. E. D., \& Sari, M. M. R. (2013). Prediksi Kebangkrutan Dengan Model Grover, Altman ZScore Springate dan Zmijewski Pada Perusahaan Food And Beverage Di Bursa Efek Indonesia. E'jurnal Akuntansi Universitas Udayana, 2, 417-435.

Sugiyono. (2010). Metode Penelitian Administrasi. Bandung: Alfabeta.

Sugiyono. (2016). Metode Penelitian Kuantitatif Kualitatif Dan $R \& D$. Bandung: Alfabeta.

Vestari, M., \& Farida, D. N. (2014). Analisis Rasio-Rasio Dan Ukuran Keuangan, Prediksi Financial Distress, Dan Reaksi Investor. AKRUAL: Jurnal Akuntansi, 5(1), 26. https://doi.org/10.26740/jaj.v5n1.p2644

Yunindra, A. E. (2018). Analisa Rasio Keuangan dalam Memprediksi Kebangkrutan Perusahaan Industri Sub Sektor Textile d an Garment yang Terdaftar di Bursa Efek Indonesia Oleh : Andri Eka Yunindra, 20. 